\title{
Clinical features and treatment of spinal metastatic pheochromocytoma and paraganglioma: a single institutional experience with 18 patients
}

\author{
Suiyong Du \\ Peking University Third Hospital \\ Panpan Hu \\ Peking University Third Hospital \\ Shaomin Yang \\ Peking University Third Hospital \\ Hongqing Zhuang \\ Peking University Third Hospital \\ Feng Wei ( $\square$ puth_wf@163.com ) \\ Peking University Third Hospital \\ Xiaoguang Liu \\ Peking University Third Hospital \\ Zhongjun Liu \\ Peking University Third Hospital
}

\section{Research Article}

Keywords: Pheochromocytoma, paraganglioma, metastasis, spine, surgery, adjuvant therapies

Posted Date: July 12th, 2021

DOI: https://doi.org/10.21203/rs.3.rs-687720/v1

License: (c) (i) This work is licensed under a Creative Commons Attribution 4.0 International License. Read Full License 


\section{Abstract}

Pheochromocytomas and paragangliomas (PPGLs) are rare neuroendocrine tumors, which can potentially metastasize to the spine. Clinical researches and treatment guideline on this entity are lacking. This study described the clinical features and treatment outcomes of metastatic PPGLs on the spine. We reviewed 18 patients with spinal PPGLs who were consecutively treated in our spinal center. The cohort included ten cases of pheochromocytomas and eight paragangliomas. The local pain and neurological deficits were the two most common symptoms. One third of the spinal PPGLs were diagnosed as functional tumors. The surgical strategies for the cohort included percutaneous vertebroplasty, neurological decompression and partial tumor resection with or without internal fixation, and total en-bloc resection. The postoperative courses were uneventful except one patient developed heart failure. The adjuvant therapies were implemented in six patients with ${ }^{131}$ I-MIBG, five with radiotherapy, two with chemotherapy and one with target therapy. The median survival period was 39 months. The patients' Karnofsky performance scores were positively correlated with the overall survival $(p<0.05)$. Therefore, surgery is indicated for intractable local pain and neurological impairment in the patients with spinal PPGLs, while a holistic set of adjuvant therapies shall be incorporated for a better tumor control.

\section{Introduction}

Pheochromocytoma and paragangliomas (PPGLs) are rare endocrine tumors arising from chromaffin cells, which are derived from the neural crest [1, 2]. According to the 2017 World Health Organization (WHO) classification system [3], Pheochromocytoma (PHEO) is an adrenal tumor, and paragangliomas (PGL) is an extra-adrenal tumor. Since the two tumor types cannot be differentiated on the basis of histologic findings, anatomical location is used to distinguish between them. PHEO develops from the adrenal medulla, while PGL arises in extra-adrenal sites, including the abdomen, thorax, head and neck. PPGLs has a low incidence, which is estimated at 2 to 8 cases per million per year, in which PHEOs are more common than PGLs [1, 4]. These neoplasms are mostly seen in the age of 4 th to 6 th decades, and do not show significant gender disparity. PPGLs have the capacity to synthesize, store, and secrete a variety of neurotransmitters, especially catecholamine, which predispose the patients to symptoms such as hypertension, palpitations, throbbing headaches, and diaphoresis $[1,5]$. However, their clinical manifestations are extremely variable, depending on locoregional and distant involvement, tumor size, the secretion of catecholamines and function of altitude, and the malignancy potential $[1,2,4,6]$.

All PPGLs have the potential to metastasis, according to the last WHO classification in 2017 [3]. The prevalence of metastasis to non-chromaffin organs and structures is estimated $10 \%$ in PHEOs and $35-40 \%$ in PGLs, relatively $[1,4,6,7]$. The common metastases include lymph nodes, liver, lung, urinary systems and bone $[4,6]$. Spinal involvement is rare and was sporadically reported [8-17].Currently, no mature guideline on the treatment of metastatic spinal PPGLs exists.Surgical resection is the treatment of choice for the spinal lesions, and a complete resection remains the goal of surgery, which, however, is hard to achieve due to the complex anatomic structures, adjacent to vital organs and heavy bleeding due to hypervascularity $[4,7,16,18]$. In the present study, we retrospectively reviewed the patients who were consecutively treated in our spinal center and described their clinical features and surgical outcomes. Furthermore, we searched medical databases for reports, case series and researches on metastatic spinal PPGLs, in order to present a deep and precise appraisal of current therapeutic modalities.

\section{Materials And Methods}

\section{Patients inclusion}

The clinical data of 18 patients with metastatic spinal PPGLs, who were consecutively treated in our spinal center from May 2007 and August 2019 , were reviewed. The inclusion criteria were as the following: 1) having a past history of PHEOs or PGLs, and the pathological specimens of spinal lesions were confirmed by the department of pathology in our center; 2) receiving surgical treatment in our center; 3) being regularly followed-up; and 4) the clinical data were fully accessible. This study was approved by our institutional ethics committee, and the written informed consent was obtained from all the patients.

\section{Data collection}

In this study, we mainly focused on the review and analysis of clinical features, treatment information and follow-up data regarding spinal metastatic lesions. Specifically, the neurological status was rated according to ASIA scaling system. The life capacity of the patients was assessed with the Karnofsky performance scale (KPS) [19]. The Spinal Instability Neoplastic Score (SINS) system was used to assess spinal stability [20], and the Tomita and Tokuhashi scoring systems were used to assess the prognosis of patients and assist in the scheming of surgical plans [21, 22]. The advice from our institutional multidisciplinary team on the spinal tumors was also incorporated into the plans. The surgical strategies were categorized as the following: total resection (TR), partial resection (PR, including separation surgeries), and percutaneous vertebroplasty procedures (PVP). Besides, neurological decompression was undertaken in case of symptoms and signs of neurological compression. Surgical data, including blood loss, duration and perioperative complications, were reviewed and analyzed. The surgical outcomes were appraised mainly using overall survival (OS) after the indexed operation.

\section{Statistical analysis and data presentation}

Data analysis was performed using IBM SPSS statistics for Windows Version 20 (IBM Corp., Armonk, NY, USA). Lilliefors test, which is an adaptation of the Kolmogorov-Smirnov test, was used to examine whether the data were normally distributed. Data presentation was provided in the forms of percentages, mean \pm standard deviation, or median (range). Two-tailed unpaired Student's $t$ test and two-tailed Pearson's $\chi 2$ test (or Fisher's exact test) were utilized to make a comparison between different groups. Spearman's rank correlation test was used for correlation analysis between the two parameters. Statistical significance was set at 0.05 .

\section{Results}




\section{Demographic data and medical history}

This study had ten cases of PHEOs and eight cases of PGLs (Table 1). All patients received one year of follow-up at least. The cohort included 13 males and five females, and the median age was 45.1 years. 15 patients were initially referred to our institution for metastatic spinal PPGLs, and three had history of surgical interventions of spinal metastases in other hospitals. Half of the cases had history of local recurrence and/or metastasis to other organs. The period between the surgical resection of primary sites and the emergence of the spinal metastases ranged ten to 326 months, with a median of 32.5 months.

Table 1

Clinical data and medical history of the included cohort

\begin{tabular}{|c|c|c|c|c|c|}
\hline $\begin{array}{l}\text { Case } \\
\text { No. }\end{array}$ & $\begin{array}{l}\text { Age } \\
\text { (years)/sex }\end{array}$ & Primary site, year & Pathologies & Local control & Other metastasis* \\
\hline 1 & $32 \mathrm{y} / \mathrm{M}$ & Adrenal, 2006 & Pheochromocytoma & Recurrence, 2007 & No \\
\hline 2 & $42 \mathrm{y} / \mathrm{M}$ & Adrenal, 2008 & Pheochromocytoma & Stable & No \\
\hline 3 & $47 \mathrm{y} / \mathrm{F}$ & Adrenal, 2013 & Pheochromocytoma & Stable & No \\
\hline 4 & $50 \mathrm{y} / \mathrm{M}$ & Adrenal, 2015 & Pheochromocytoma & Stable & No \\
\hline 5 & $55 \mathrm{y} / \mathrm{F}$ & Adrenal, 2010 & Pheochromocytoma & Recurrence, 2015 & Liver, 2018 \\
\hline 6 & $30 \mathrm{y} / \mathrm{M}$ & Adrenal, 2011 & Pheochromocytoma & Recurrence, 2016 & No \\
\hline 7 & $57 \mathrm{y} / \mathrm{M}$ & Adrenal, 2014 & Pheochromocytoma & Stable & No \\
\hline 8 & $46 \mathrm{y} / \mathrm{M}$ & Adrenal, 1992 & Pheochromocytoma & $\begin{array}{l}\text { Recurrence, 1994, } \\
2008,2013\end{array}$ & No \\
\hline 9 & $20 \mathrm{y} / \mathrm{M}$ & Mediastinum, 2005 & Paraganglioma & Stable & No \\
\hline 10 & $47 y / M$ & Bladder, 2001 & Paraganglioma & Stable & Left ilium and rib, 2014 \\
\hline 11 & $63 \mathrm{y} / \mathrm{M}$ & Bladder, 2013 & Paraganglioma & Stable & Lung, 2015 \\
\hline 12 & $56 \mathrm{y} / \mathrm{M}$ & Retroperitoneum, 2012 & Paraganglioma & Stable & No \\
\hline 13 & $27 \mathrm{y} / \mathrm{M}$ & Retroperitoneum, 2013 & Paraganglioma & Recurrence, 2016 & $\begin{array}{l}\text { Cervical lymph nodes and Left } \\
\text { acetabulum, } 2016\end{array}$ \\
\hline 14 & $58 \mathrm{y} / \mathrm{M}$ & Retroperitoneum, 2014 & Paraganglioma & $\begin{array}{l}\text { Recurrence, 2012, } \\
2015\end{array}$ & No \\
\hline 15 & $51 \mathrm{y} / \mathrm{M}$ & Retroperitoneum, 2016 & Paraganglioma & Recurrence, 2018 & Lung and liver, 2018 \\
\hline 16 & $47 \mathrm{y} / \mathrm{F}$ & $\begin{array}{l}\text { Neck, superior mediastinum } \\
\text { tumors, } 2016\end{array}$ & Paraganglioma & Stable & No \\
\hline 17 & $42 \mathrm{y} / \mathrm{F}$ & Adrenal, 2005 & Pheochromocytoma & Stable & Liver, 2007 \\
\hline 18 & $42 \mathrm{y} / \mathrm{F}$ & Adrenal, 2006 & Pheochromocytoma & Stable & No \\
\hline
\end{tabular}

\section{Symptoms and imaging findings}

Local pain was the most common symptom, as a percentage of 72.2\% (13/18), and 66.7\% (12/18) presented with different degrees of neurological deficits, including myelopathy and/or radiculopathy (Table 2). There were twelve cases (66.7\%) of nonfunctional PPGLs and six cases (33.3\%) of functional PPGLS that aroused different degrees of hypertension. According to the preoperative imaging work-ups, the imaging manifestations of the spinal metastases were consistent with osteolytic lesions (Fig. 1). They usually had no signs of calcification inside the mass. PET/CT and bone scan revealed abnormal high concentrations within the mass (Fig. 1). There were ten cases (55.6\%) of solitary vertebral body metastasis and eight cases of multiple vertebral bodies with or without other visceral and lymph node metastases (Table 2 and Fig. 1). The whole mobile spine and sacrum were candidates for metastasis, with the thoracic spine involving in ten cases, lumbar in seven, cervical in four and sacrum in one case. 
Table 2

Clinical features, treatment and outcomes of the metastatic spinal PPGLs.

\begin{tabular}{|c|c|c|c|c|c|c|c|c|c|c|}
\hline $\begin{array}{l}\text { Case } \\
\text { No. }\end{array}$ & $\begin{array}{l}\text { Spinal } \\
\text { metastases, } \\
\text { time }\end{array}$ & Symptoms & $\begin{array}{l}\text { Karnofsky } \\
\text { Performance } \\
\text { score }\end{array}$ & $\begin{array}{l}\text { SINS } \\
\text { score }\end{array}$ & $\begin{array}{l}\text { Surgical } \\
\text { strategies* }\end{array}$ & $\begin{array}{l}\text { Blood } \\
\text { loss } \\
(\mathrm{ml})\end{array}$ & $\begin{array}{l}\text { Postoperative } \\
\text { complications }\end{array}$ & $\begin{array}{l}\text { ASIA score } \\
\text { (pre/postop) }\end{array}$ & $\begin{array}{l}\text { Adjuvant } \\
\text { therapies }\end{array}$ & $\begin{array}{l}\text { Follow- } \\
\text { Up } \\
\text { (months) }\end{array}$ \\
\hline 1 & $\begin{array}{l}\text { Multiple, } \\
\text { Mar } 2012\end{array}$ & Local pain & 60 & 13 & $\begin{array}{l}\text { PVP for T4 and } \\
\text { T5 }\end{array}$ & 20 & None & $\mathrm{D} / \mathrm{E}$ & MIBG therapy & $\begin{array}{l}\text { Alive } \\
\text { with } \\
\text { disease, } \\
96\end{array}$ \\
\hline 2 & $\begin{array}{l}\text { Multiple, } \\
\text { Mar } 2014\end{array}$ & $\begin{array}{l}\text { Local pain } \\
\text { and ND }\end{array}$ & 80 & 6 & $\begin{array}{l}\text { Decompression } \\
\text { with PR for S1 }\end{array}$ & 800 & None & $E / E$ & Radiotherapy & $\begin{array}{l}\text { Alive } \\
\text { with } \\
\text { disease, } \\
84\end{array}$ \\
\hline 3 & $\begin{array}{l}\text { C2, Jul } \\
2015\end{array}$ & Local pain & 80 & 14 & TR & 1600 & None & $\mathrm{D} / \mathrm{E}$ & None & $\begin{array}{l}\text { Alive } \\
\text { with } \\
\text { disease, } \\
53\end{array}$ \\
\hline 4 & $\begin{array}{l}\text { T2, Jul } \\
2016\end{array}$ & $\begin{array}{l}\text { Local pain, } \\
\text { ND and } \\
\text { secondary } \\
\text { hypertension }\end{array}$ & 40 & 14 & $\begin{array}{l}\text { Decompression } \\
\text { with PR }\end{array}$ & 1200 & None & $C / D$ & MIBG therapy & Death,12 \\
\hline 5 & $\begin{array}{l}\text { L4, Dec } \\
2018\end{array}$ & $\begin{array}{l}\text { Local pain, } \\
\text { ND and } \\
\text { secondary } \\
\text { hypertension }\end{array}$ & 40 & 18 & $\begin{array}{l}\text { Decompression } \\
\text { with PR }\end{array}$ & 1200 & None & $B / D$ & MIBG therapy & $\begin{array}{l}\text { Death, } \\
14\end{array}$ \\
\hline \multirow[t]{2}{*}{6} & $\begin{array}{l}\text { T12, Dec } \\
2018\end{array}$ & Local pain & 50 & 6 & PR & 700 & $\begin{array}{l}\text { pulmonary } \\
\text { infection }\end{array}$ & $A / D$ & None & Death, 4 \\
\hline & & & & & & & $\begin{array}{l}\text { Massive } \\
\text { thoracic } \\
\text { hemorrhage }\end{array}$ & & & \\
\hline 7 & $\begin{array}{l}\text { T5, Nov } \\
2019\end{array}$ & $\begin{array}{l}\text { Local pain, } \\
\text { ND and } \\
\text { secondary } \\
\text { hypertension }\end{array}$ & 40 & 16 & $\begin{array}{l}\text { Decompression } \\
\text { with PR }\end{array}$ & 1000 & None & $\mathrm{A} / \mathrm{A}$ & Radiotherapy & Death, 5 \\
\hline 8 & $\begin{array}{l}\text { C1, Dec } \\
2018\end{array}$ & $\begin{array}{l}\text { Local pain } \\
\text { and } \\
\text { secondary } \\
\text { hypertension }\end{array}$ & 80 & 18 & PR & 1200 & None & $E / E$ & Radiotherapy & $\begin{array}{l}\text { Alive } \\
\text { with } \\
\text { disease, } \\
27\end{array}$ \\
\hline 9 & $\begin{array}{l}\text { T6, Oct } \\
2010\end{array}$ & ND & 90 & 15 & $\begin{array}{l}\text { Decompression } \\
\text { with PR }\end{array}$ & 800 & None & $\mathrm{D} / \mathrm{E}$ & None & $\begin{array}{l}\text { Alive } \\
\text { with } \\
\text { disease, } \\
125\end{array}$ \\
\hline 10 & $\begin{array}{l}\text { T12, Feb } \\
2014\end{array}$ & $\begin{array}{l}\text { Local pain } \\
\text { and } \\
\text { secondary } \\
\text { hypertension }\end{array}$ & 80 & 9 & PR & 2000 & Heart failure & $\mathrm{D} / \mathrm{E}$ & MIBG therapy & $\begin{array}{l}\text { Death, } \\
10\end{array}$ \\
\hline 11 & $\begin{array}{l}\text { Multiple, } \\
\text { Jan } 2015\end{array}$ & $\begin{array}{l}\text { Local pain } \\
\text { and ND }\end{array}$ & 60 & 9 & $\begin{array}{l}\text { Decompression } \\
\text { with PR }\end{array}$ & 1600 & None & $E / E$ & Chemotherapy & $\begin{array}{l}\text { Death, } \\
39\end{array}$ \\
\hline 12 & $\begin{array}{l}\text { L3, May } \\
2015\end{array}$ & ND & 80 & 6 & $\begin{array}{l}\text { Decompression } \\
\text { with PR }\end{array}$ & 200 & None & $E / E$ & Radiotherapy & $\begin{array}{l}\text { Alive } \\
\text { with } \\
\text { disease, } \\
70\end{array}$ \\
\hline 13 & $\begin{array}{l}\text { Multiple, } \\
\text { Jun } 2016\end{array}$ & ND & 50 & 13 & $\begin{array}{l}\text { Decompression } \\
\text { with PR }\end{array}$ & 1100 & None & $\mathrm{C} / \mathrm{C}$ & MIBG therapy, & $\begin{array}{l}\text { Death, } \\
38\end{array}$ \\
\hline 14 & $\begin{array}{l}\text { Multiple, } \\
\text { Feb } 2017\end{array}$ & $\begin{array}{l}\text { Local pain } \\
\text { and } \\
\text { secondary } \\
\text { hypertension }\end{array}$ & 60 & 12 & $\begin{array}{l}\text { Decompression } \\
\text { with PR }\end{array}$ & 300 & None & $E / E$ & MIBG therapy & $\begin{array}{l}\text { Alive } \\
\text { with } \\
\text { disease, } \\
100\end{array}$ \\
\hline 15 & $\begin{array}{l}\text { C7, Oct } \\
2018\end{array}$ & ND & 70 & 15 & $\begin{array}{l}\text { Decompression } \\
\text { with PR }\end{array}$ & 900 & None & $E / E$ & Radiotherapy & $\begin{array}{l}\text { Alive } \\
\text { with } \\
\text { disease, } \\
29\end{array}$ \\
\hline 16 & $\begin{array}{l}\text { L1, May } \\
2019\end{array}$ & Local Pain & 70 & 13 & PR & 800 & None & $E / E$ & Anlotinib & $\begin{array}{l}\text { Alive } \\
\text { with } \\
\text { disease, } \\
22\end{array}$ \\
\hline
\end{tabular}

*Instrumented fixation was performed in all cases but case \#1 and \#2.

PPGL stands for pheochromocytoma and paraganlioma; SINS, spinal instability neoplastic score; ND, neurological deficits; PR, partial resection of the tumor; TR, total resection of the tumor; PVP, percutaneous vertebroplasty; MIBG, metaiiodo-benzylguanidine. 


\begin{tabular}{|c|c|c|c|c|c|c|c|c|c|c|}
\hline $\begin{array}{l}\text { Case } \\
\text { No. }\end{array}$ & $\begin{array}{l}\text { Spinal } \\
\text { metastases, } \\
\text { time }\end{array}$ & Symptoms & $\begin{array}{l}\text { Karnofsky } \\
\text { Performance } \\
\text { score }\end{array}$ & $\begin{array}{l}\text { SINS } \\
\text { score }\end{array}$ & $\begin{array}{l}\text { Surgical } \\
\text { strategies* }\end{array}$ & $\begin{array}{l}\text { Blood } \\
\text { loss } \\
(\mathrm{ml})\end{array}$ & $\begin{array}{l}\text { Postoperative } \\
\text { complications }\end{array}$ & $\begin{array}{l}\text { ASIA score } \\
\text { (pre/postop) }\end{array}$ & $\begin{array}{l}\text { Adjuvant } \\
\text { therapies }\end{array}$ & $\begin{array}{l}\text { Follow- } \\
\text { Up } \\
\text { (months) }\end{array}$ \\
\hline 17 & $\begin{array}{l}\text { T4, May } \\
2007\end{array}$ & ND & 60 & 15 & $\begin{array}{l}\text { Decompression } \\
\text { with PR }\end{array}$ & 2500 & None & $\mathrm{C} / \mathrm{E}$ & None & $\begin{array}{l}\text { Death, } \\
35\end{array}$ \\
\hline 18 & $\begin{array}{l}\text { L1, Aug } \\
2010\end{array}$ & $\begin{array}{l}\text { Local pain } \\
\text { and ND }\end{array}$ & 40 & 14 & $\begin{array}{l}\text { Decompression } \\
\text { with PR }\end{array}$ & 900 & None & $\mathrm{A} / \mathrm{A}$ & Chemotherapy & $\begin{array}{l}\text { Death, } \\
17\end{array}$ \\
\hline
\end{tabular}

*Instrumented fixation was performed in all cases but case \#1 and \#2.

PPGL stands for pheochromocytoma and paraganlioma; SINS, spinal instability neoplastic score; ND, neurological deficits; PR, partial resection of the tumor; TR, total resection of the tumor; PVP, percutaneous vertebroplasty; MIBG, metaiiodo-benzylguanidine.

\section{Surgical strategies and adjuvant therapies}

Surgical options for the cohort included PVP in one case (case \#1), en-bloc tumor resection in one case (case \#3, and Fig. 2), and partial tumor resection in the other 16 cases, among whom 13 cases received instrumented fixation and neurological decompression procedures in 12 cases. The mean bleeding volume for open surgeries in 17 cases was 1105.9 ml. Histological and immunostaining results of the removed specimens were consistent with PPGLs (Fig. 3). Preoperative embolization was performed in three patients to mitigate the bleeding during the operation. The postoperative course was uneventful in 17 patients, but one patient (case \#10) developed heart failure (Table 2).

Adjuvant therapies were offered according to the advice from our institutional multidisplinary treatment (MDT) team on spinal tumors. Five patients were treated with radiotherapy, two patients treated with chemotherapy, six patients treated with iodine(131)-metaiodobenzylguanidine $\left({ }^{131} \mathrm{I}-\mathrm{MIBG}\right)$, and one patients treated with targeted therapy. The other four patients did not receive adjuvant therapies (Table 2).

\section{Follow-up results}

Up to the last follow-up, eight patients died due to tumors or tumor-related events from five to 39 months after the operation, and one patient (case \#6) died of pulmonary infection and thoracic hemorrage four months after the operation. The 1 -year OS rates were $77.8 \%$ and the median survival period was 39.0 months (Fig. 4). We found that survival period was related with numbers of spinal metastases (solitary versus multiple, $\mathrm{p}<0.05$, two-tailed student $t$ test) and that significantly correlated with KPS (rho $=0.537, p<0.05$, Spearman's correlation analysis).

\section{Discussion}

PHEOs and PGLs have the same cellular origin. They are generally slow-growing but all have potentials of recurrence and metastasis, according to the last WHO classification (2017 version) on endocrine tumors, which eliminated benign versus malignant discrimination [1, 3]. In the clinical practice, the patients of PPGL are usually latent until huge massing effect and/or metastasis has occurred. Previous researches identified some factors associated with higher risk of metastasis, including the primary tumor site and size, age at diagnosis and some specific genotypes [1,3-7, 23]. The bone is one of the most common metastatic sites (72\%), and the spinal involvement is one of the most deadly situation $[24,25]$. Metastatic spinal PPGLs can significantly impair patients' activity of daily living and quality of life, due to the emergence of devastating skeletal-related events, such as pathological fracture and severe local pain and paraplegia [24]. Literature regarding this entity is lacking, so few references are currently availed about the clinical features and treatment outcomes of the spinal metastasis. In this report, we described and analyzed a cohort of 18 patients with metastatic spinal PPGLs, hoping to provide references for the future clinical practice in this field.

This study found that the spinal PPGL was mostly seen in mid-aged patients (Table 1), and that $94.4 \%$ (17/18) cases were younger than 60 years. The study noted gender variation with a predominance of males (2.6/1). The time between the prior surgery of primary site and the spinal metastasis varied in a wide range, from one to 27 years. The clinical symptoms of the cohort were not pathognomonic. Local pain and neurological dysfunction were related to bony erosion and pathological fractures. As the primary PPGLs, metastatic lesions can also be functional, which are capable to secrete catecholamines (Table 2). Typical catecholamine-arousing symptoms include headache, palpitation, fatigue, flushing, sweating and/or paroxysmal hypertension [1, 4, 24].In our case series, there were six patients $(33.3 \%, 6 / 18)$ having secondary hypertension, which were presumably related to the metastases. Malignant hypertension may cause a series of hemodynamic disorders and vascular events [1,25]. As previously reported, we prepared these patients with a-adrenergic receptor antagonists, in avoidance of perioperative hypertension crisis and lethal vascular events $[1,4,6,25]$.

In this study, all cases had different extents of pathological fractures, from cortical destruction to severe vertebral collapse. The thoracic spine was the most susceptible metastatic sites, as a percentage of 55.6\%. The imaging manifestations of metastatic PPGLs were consistent with other osteolytic lesions. CT and MRI scans are the modalities of choice to identify the involved vertebral segments. On CT films, the lesions usually a homogenously osteolytic mass within the vertebral body, with paraspinal soft tissue mass in some cases. Different from the inflections and metabolic bone diseases, the surrounding cancellous bone is normal and no existence of sclerotic girdle. On MRI scans, the lesion is a mass with hypointensive signal on T1-weighted images and hyperintense signal on T2-weighted images (Fig. 1). Sometimes, we could find the signs of vascular flow void on T2 sequences, due to the heavy vascularity in some cases $[16,18]$.

The treatment strategies of the case series were schemed by our institutional MDT team in a concerted way. As for spinal metastases, a holistic set of treatment modalities are emphasized, including surgery, radiotherapy, chemotherapy and/or other anti-tumor therapies $[4,7,11,16,25]$. Preoperative evaluation was carried out by our MDT team. Especially, the patients' physical condition (KPS), the spinal instability neoplastic score (SINS), Tokuhashi and Tomita staging systems were evaluated, to facilitate the scheming of surgical strategies. Surgical resection is the most effective way to reduce the tumor 
burden, and it is recognized as the treatment of choice for spinal PPGLs, especially for those with intractable local pain and neurological impairment [4, 16, 25-28]. Preoperative hemodynamic reconditioning is essential to the safety of the operation. Preoperatively, adrenergic blockade is typically accomplished with either a nonselective or a selective a-adrenergic receptor antagonist (e.g., phenoxybenzamine, and doxazosin), usually started at least one week before surgery $[7,15,27]$.The ßadrenergic antagonist should be administered to control tachycardia after aadrenergic blockade has been effective in normalizing blood pressure. Another precaution needs to be taken into account in the surgical planning of metastatic spinal PPGLs: the vascularity of the tumor. This spinal metastasis tends to be hypervascular, which can lead to significant blood loss intraoperatively. Our case series had an over $1100 \mathrm{ml}$ of blood loss averagely. It has been suggested that preoperative embolization of the supplying arteries $24 \mathrm{~h}-48 \mathrm{~h}$ before surgery can minimize blood loss [18].

Palliative surgeries, including separation surgeries, neurological decompression and vertebral augmentation procedures, are the mainstay of treatment choice, for the patients with multiple metastases, recurrent spinal lesions, acute neurological deterioration and intractable local pain. In our case series, 17 patients underwent palliative surgeries, and the main surgical goals were to restore the spinal stability with or without decompress the neurological elements. In recent years, separation surgery has gained wide acceptance for metastatic spinal tumors. In our series, the surgeries of 13 patients were performed under the principles of separation surgeries. Within the operation, two therapeutic goals were achieved, namely sufficient neurological decompression and sparing a safe distance for radiotherapy. Percutaneous vertebral augmentation procedure was proven to be an effective method to control the local pain for the patients with no symptoms of neurological impairment (case \#1).

For the patients with solitary spinal metastasis, total resection shall be attempted. PPGLs have a high recurrent rate when partially resected. Richter et al. [13] reported that total en-bloc spondylectomy complemented with radiotherapy led to tumor-free survival at the 10-year follow-up in their patient. Yin et al. [16] shared a series of 18 patients with spinal PGLs and 15 of them received total tumor resection. The surgical outcomes were encouraging, with a relapse-free period over 40 months. However, given the intricate growth pattern and encasement of neural tissue by spinal metastases, intrusion to the spinal cord and paraspinal vital structures, and heavy bleeding during the surgery, total resection is not always feasible. Therefore, we should make a reasonable choice, based on the balance of the safety and efficacy of tumor resection for each surgical option. In recent years, the advances in the surgical tools and instruments, such as 3D printing prosthetic vertebra and ultrasonic bone scalpel, facilitate the challenging procedure of tumor resection [29, 30]. Even in the procedures of $\mathrm{PR}$, maximal tumor mass resection should be attempted, to reduce the tumor load and spare more space in avoidance of relapse of neurological compression.

Locoregional recurrence or progression is a big concern for patients with spinal tumors. When removal of the entire tumor is not possible, radiation treatment is recommended $[1,16,24]$. The doses delivered to our cases ranged $35 \mathrm{~Gy}$ to $45 \mathrm{~Gy}$. The dose was referred to studies performed on giant cell tumors and chordomas. Overall, among the patients treated with radiotherapy in our study, four patients survived more than two years and one died five months after the indexed surgery. For the past several decades, systemic therapies for PPGLs have been mainly referred to ${ }^{131} \mathrm{I}$-MIBG. Current knowledge of systemic therapies relies on the results of a few mainly retrospective studies [25]. Up to $70 \%$ of metastatic PPGLs do not respond to the treatment [32]. Overall, six patients in our study were treated with ${ }^{131} \mathrm{I}$-MIBG, while three patients died ten to 14 months after the therapy, one died 38 months later and the other two patients enjoyed a long survival. The outcomes suggest that the use and efficacy of ${ }^{131} \mathrm{I}-\mathrm{MIBG}$ therapy in spinal PPGLs needs further exploration and verification.

The use of chemotherapy is controversial. The chemotherapeutic drugs are various for metastatic PPGLs, including almost all currently available agents. The single or combined use of chemotherapeutic drugs is practically experience based given the rarity of the diseases. CVD regimen (cyclophosphamide, vincristine and dacarbazine) is recommended as the best protocol. Ayala-Pamirez et al. [24] reported that 5-year OS rate of PPGLs patients who received CVD regimen was $51 \%$. A meta-analysis found that only 37\% of malignant PPGLs showed response to the regimen [33].U-King-Im et al [32] reported successful therapeutic use of octreotide in a patient with carotid body PGL that metastasized to multiple vertebrae. Mertens et al. [11] demonstrated the successful regression and palliation of metastases of PGL with chemotherapy, particularly with the CVD regimen. However, the application and efficacy of chemotherapy after the surgeries were not well established and in need of support from high-quality, large-scale clinical trials. Radiotherapy is a valuable adjuvant therapy for spinal tumors after the operation, to provide a better locoregional control for the cases with residual tumor mass. In our cohort, five out of 13 patients who underwent separation surgeries received radiotherapy after the operation, among whom one patient died five after the therapy and the other four patients manifested a satisfying local control after more than 2 years of follow-up.

The present study has several limitations. Firstly, it is a retrospective study with a small sample size. Thus, the results of this study need further examination and references with caution.. Secondly, the primary tumors were operated many years ago in other hospitals, so access to information related to surgical margin status, the size of the primary tumor, and treatment after primary tumor resection was limited. Thirdly, it was difficult to obtain the continuity, regularity, periodicity and dose of radiotherapy and chemotherapy after the indexed surgeries for spinal PPGLs, because some of adjuvant therapies were not implemented in our hospital.

\section{Conclusions}

This study described the clinical features, surgical strategies and outcomes of metastatic spinal PPGLs. The spinal metastases were generally latent and did not be recognized until local pain and the occurrence of neurological deficits. Functional spinal PPGL is a big concern during the surgical preparation and hemodynamic reconditioning with a-adrenergic receptor antagonists recommended as the management of primary PPGLs, to avoid severe vascular events. PPGLs are very vascular tumors, so preoperative embolization of supplying vessels is recommended to mitigate the blood loss during the operation. The median survival period was 39 months and 1-year OS rate was $77.8 \%$. Surgery is the treatment of choice for spinal PPGLs, and palliative surgery combined with ${ }^{131}$ I-MIBG and/or radiotherapy was proven a feasible and safe therapeutic strategy, with fair outcomes.

\section{Declarations}


We thank our institutional multidisplinary treatment team on spinal tumors including colleagues from departments of anesthesiology, pathology, oncology, intensive care unit and radiotherapy for their participation in the treatment scheming and implementation and in the preparation of this article.

\section{Author contributions}

S. Du and P. Hu designed the study, reviewed the patients, collected and process the clinical data, and drafted the manuscript. S. Yang and H. Zhuang reviewed the patients and collected the data. F. Wei designed the study, selected the patients, processed the data and supervised the study. X. Liu and Z. Liu supervised the data collection and processing. All authors reviewed this manuscript.

\section{Ethics statement and approval}

The study was approved by the institutional ethics committee of Peking University Third Hospital, and performed in accordance with the ethical standards of the Declaration of Helsinki (1964) and its subsequent amendments.

\section{Funding}

This study was supported by the institutional research fund (Peking University Third Hospital; grant number: Y73504-03; recipient: F. Wei). The funds have no influence on the design of the study and data collection, analysis, and interpretation of data and in the preparation of the manuscript.

\section{Competing interests}

None

\section{References}

1. Neumann, H. P. H. \& Young, W. F. Jr, \&Eng, C.Pheochromocytoma and Paraganglioma.N.. Engl. J. Med, 381 (6), $552-565$ (2019).

2. Eisenhofer, G., et al. Malignant pheochromocytoma: current status and initiatives for future progress. Endocr. Relat. Cancer.11(3),423-436 (2004).

3. Lloyd, R.V., Osamura, Y.R., Kloppel, G.,\& Rosai, J. WHO classificationof tumours of endocrine organs. Geneva: WHO Press; 2017.

4. Garcia-Carbonero, R. et al., Multidisciplinary practice guidelines for the diagnosis, genetic counseling and treatment of pheochromocytomas and paragangliomas. Clin. Transl. Oncol. 10.1007/s12094-021-02622-9(2021).

5. Harari, A. \& Inabnet, W. B. 3 Malignant pheochromocytoma: a review. Am. J. Surg, 201, 700-708 (2011).

6. Chrisoulidou, A., Kaltsas, G., Ilias, I. \& Grossman, A. B. The diagnosis and management of malignant phaeochromocytoma and paraganglioma. Endocr. Relat. Cancer, 14, 569-585 (2007).

7. Lenders, J. W. et al. Pheochromocytoma and paraganglioma: an endocrine society clinical practice guideline. J. Clin. Endocrinol. Metab, 99, 1915-1942 (2014).

8. Jack, E. A. \& Sim, J. D. A case of paraganglioma with metastasis to the spine. Br. J. Surg. 41, 103-105 (1953).

9. Osborn, R. E. \& Mojtahedi, S. Paraganglioma metastatic to the cervical spine. Comput. Radiol, 10, 167-170 (1986).

10. North, C. A., Zinreich, E. S., Christensen, W. N. \& North, R. B. Multiple spinal metastases from paraganglioma. Cancer, 66, 2224-2228 (1990).

11. Mertens, W. C., Grignon, D. J. \& Romano, W. Malignant paraganglioma with skeletal metastases and spinal cord compression: response and palliation with chemotherapy. Clin. Oncol, 5, 126-128 (1993).

12. Brodkey, J. A., Brodkey, J. S. \& Watridge, C. B. Metastatic paraganglioma causing spinal cord compression. Spine. 20, 367-372 (1995).

13. Richter, A., Halm, H. F., Lerner, T., Liljenqvist, U. R. \& Quante, M. Long-term follow-up after en bloc resection and reconstruction of a solitary paraganglioma metastasis in the first lumbar vertebral body: a case report. J. Med. Case Rep, 5, 45 (2011).

14. Prabhu, S., Jacob, J. J., Thomas, N. \& Oommen, R. Visual vignette. Solitary sacral metastasis from a malignant paraganglioma. Endocr. Pract, 14,131 https://doi.org/10.4158/EP.14.1.131 (2008).

15. Simpson, L. N. et al. Catecholamine-secreting paraganglioma of the thoracic spinal column: report of an unusual case and review of the literature. Neurosurgery, 70, E1049-1052 discussion E1052 (2012).

16. Yin, M. et al. Clinical characteristics and surgical treatment of spinal paraganglioma: A case series of 18 patients. Clin. Neurol. Neurosurg, 158, 20-26 (2017).

17. Jabarkheel, R. et al. Metastatic Paraganglioma of the Spine with SDHB Mutation: Case Report and Review of the Literature. Int. J. Spine Surg. 14, S37-S45 (2021).

18. Kwan, R. B. et al. Pre-operative embolisation of metastatic paraganglioma of the thoracic spine. J. Clin. Neurosci, 17, 394-396 (2010).

19. Mor, V., Laliberte, L., Morris, J. N. \& Wiemann, M. The Karnofsky Performance Status Scale. An examination of its reliability and validity in a research setting. Cancer. 53, 2002-2007 (1984).

20. Fisher, C. G. et al. A novel classification system for spinal instability in neoplastic disease: an evidence-based approach and expert consensus from the Spine Oncology Study Group. Spine, 35, E1221-1229 (2010).

21. Tomita, K. et al. Surgical strategy for spinal metastases. Spine. 26, 298-306 (2001).

22. Tokuhashi, Y., Matsuzaki, H., Oda, H., Oshima, M. \& Ryu, J. A revised scoring system for preoperative evaluation of metastatic spine tumor prognosis. Spine, 30, 2186-2191 (2005). 
23. Khatami, F., Mohammadamoli, M. \& Tavangar, S. M. Genetic and epigenetic differences of benign and malignant pheochromocytomas and paragangliomas (PPGLs). Endocr. Regul, 52, 41-54 (2018).

24. Ayala-Ramirez, M. et al. Bone metastases and skeletal-related events in patients with malignant pheochromocytoma and sympathetic paraganglioma. J. Clin. Endocrinol. Metab, 98, 1492-1497 (2013).

25. Jimenez, P., Tatsui, C., Jessop, A., Thosani, S. \& Jimenez, C. Treatment for Malignant Pheochromocytomas and Paragangliomas: 5 Years of Progress. Curr. Oncol. Rep, 19, 83 https://doi.org/10.1007/s11912-017-0643-0 (2017).

26. Liu, S. Z. et al. Surgical Treatment of Malignant Pheochromocytomas in Spine. Chin. Med. J, 131, 2614-2615 (2018).

27. Liu, S. et al. Clinical features and prognosis analysis of metastatic spinal pheochromocytoma: A single center retrospective study. J. Bone Oncol, 24, 100312 https://doi.org/10.1016/j.jbo.2020.100312 (2020).

28. Roman-Gonzalez, A. et al. Impact of Surgical Resection of the Primary Tumor on Overall Survival in Patients With Metastatic Pheochromocytoma or Sympathetic Paraganglioma. Ann. Surg, 268, 172-178 (2018).

29. Wei, F. et al. Upper cervical spine reconstruction using customized 3D-printed vertebral body in 9 patients with primary tumors involving C2. Ann. Transl. Med, 8, 332 https://doi.org/10.21037/atm.2020.03.32 (2020).

30. Vedantam, A. et al. Use of Navigated Ultrasonic Bone Cutting Tool for En Bloc Resection of Thoracic Chondrosarcoma: Technical Report. Oper. Neurosurg. $19,551-556(2020)$

31. van Hulsteijn, L. T., Niemeijer, N. D., Dekkers, O. M. \& Corssmit, E. P. (131)I-MIBG therapy for malignant paraganglioma and phaeochromocytoma: systematic review and meta-analysis. Clin. Endocrinol, 80, 487-501 (2014).

32. JM, U. K. I., Carroll, T. A. \& Morris, K. Vertebral metastatic chemodectoma: imaging and therapeutic octreotide. Case report. J. Neuros, 97, 106-109 (2002).

33. Niemeijer, N. D., Alblas, G., van Hulsteijn, L. T., Dekkers, O. M. \& Corssmit, E. P. Chemotherapy with cyclophosphamide, vincristine and dacarbazine for malignant paraganglioma and pheochromocytoma: systematic review and meta-analysis. Clin. Endocrinol, 81, 642-651 (2014).

\section{Figures}

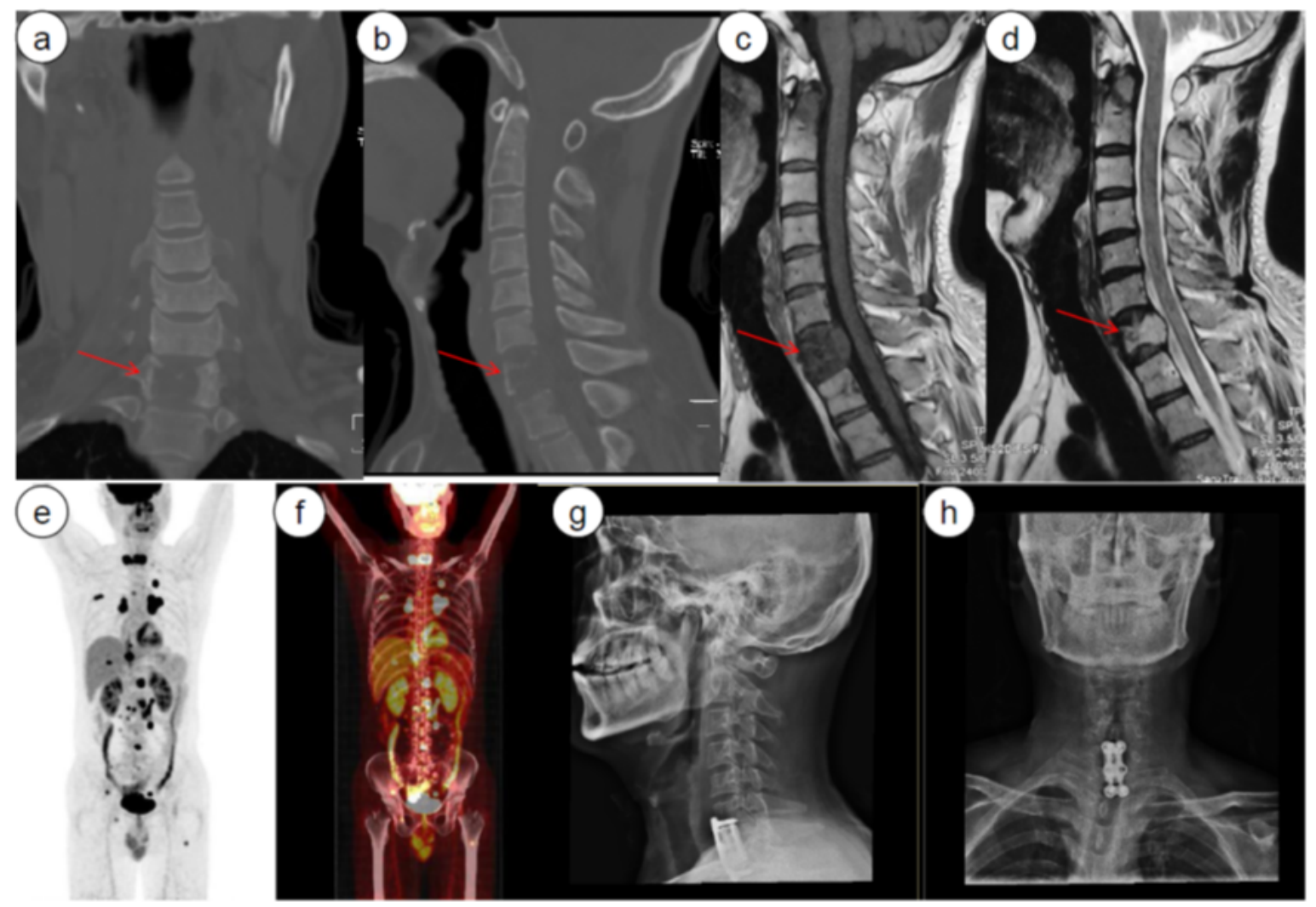

Figure 1

Imaging presentation of case \#15. CT reconstruction films revealed an osteolytic lesion inside the C7 vertebral body (arrows in a and b). The lesion showed hypo-intensive signal on T1-weighted MRI sequences and hyper-intensive signal on T2-weighted sequences (arrows in c and d). PET/CT revealed elevated uptake of 18F-FDG in multiple foci, including systemic lymph nodes, lung, liver, pelvis and spine (e and f). The patient received C7 corpectomy and spinal reconstruction with 3D-printing prosthetic vertebral body ( $g$ and $h$ ). 


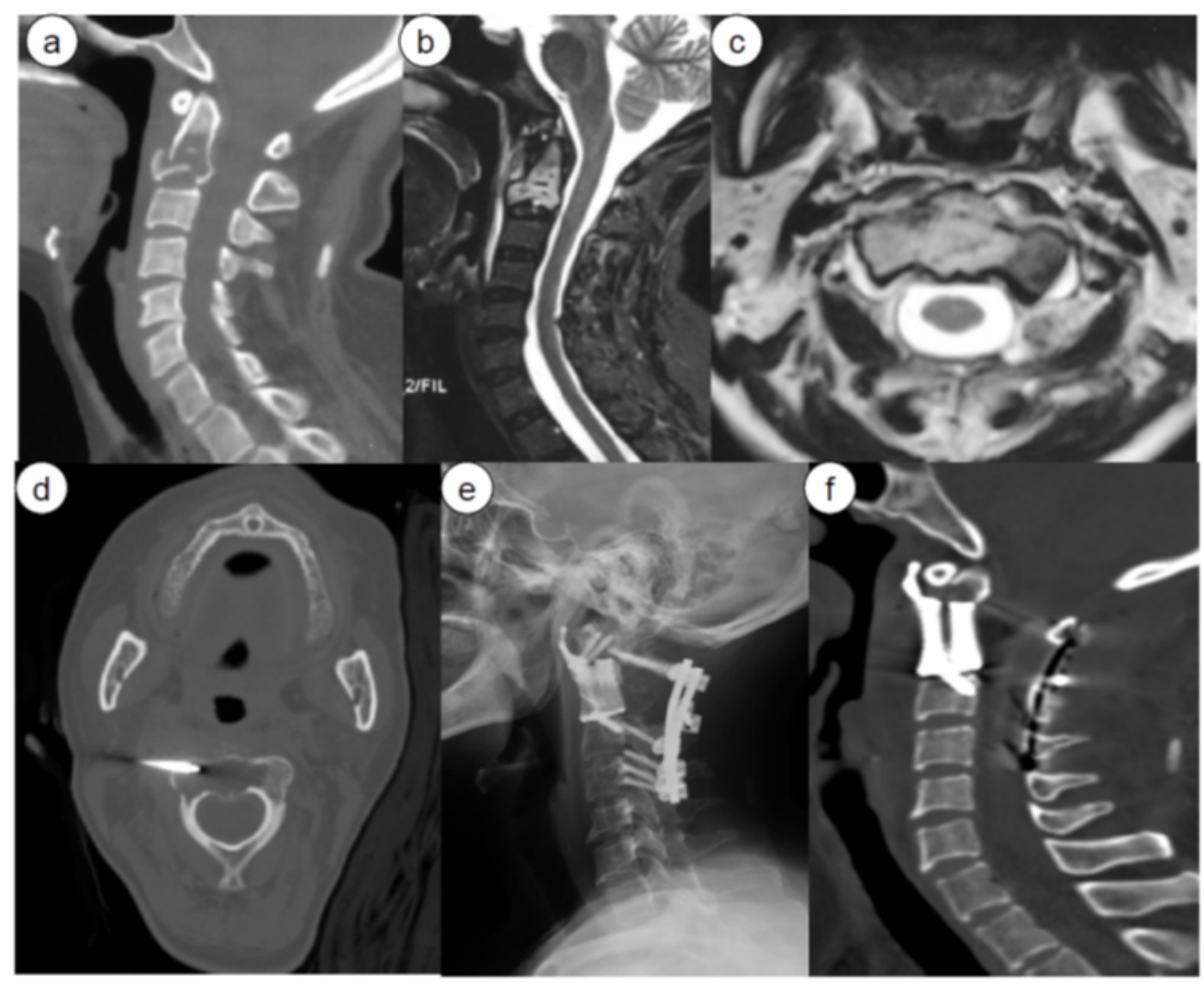

Figure 2

Presentation of total tumor resection (case \#3). Preoperative imaging work-up revealed an osteolytic lesion inside $\mathrm{C} 2$ vertebral body ( $\mathrm{a}$, b and $\mathrm{c}$ ). The patient underwent CT-guided biopsy (d) and the result was consistent with paraganglioma. There was no signs of other metastasis by PET/CT, so a total tumor resection was obtained via one-staged posterior and anterior surgical approach. The reconstruction of anterior spinal column was made with a customized 3D-printing vertebral body (e and f).

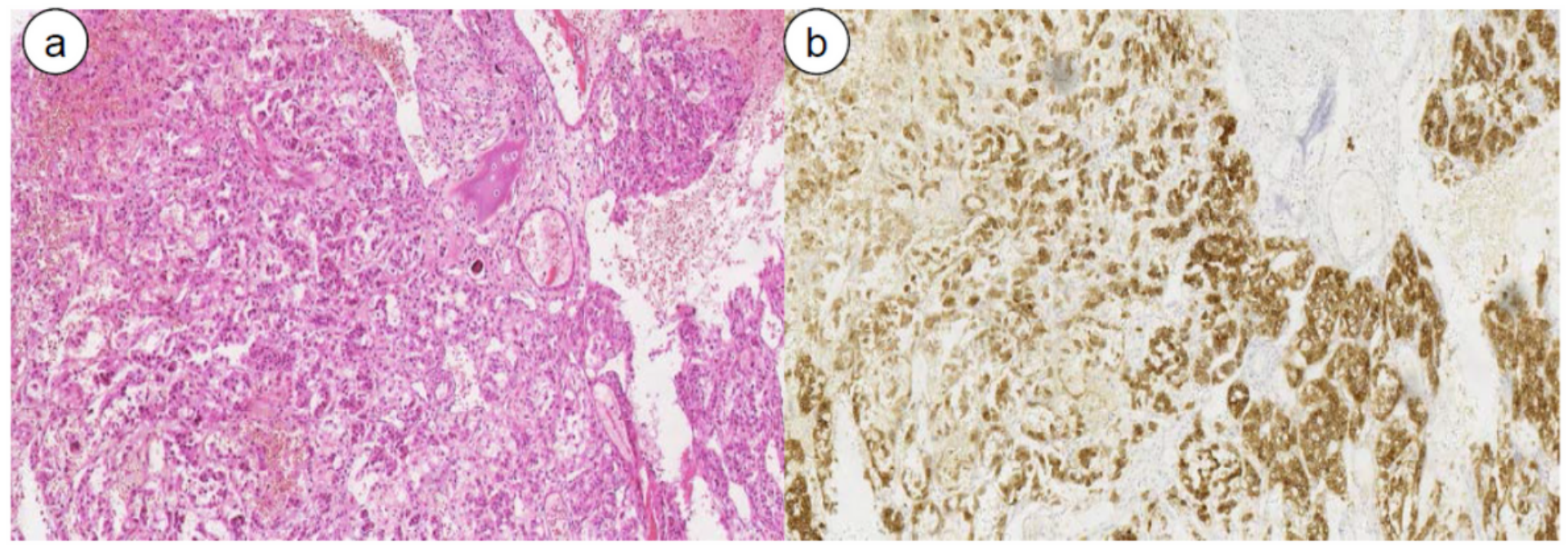

\section{Figure 3}

Histological result of spinal lesion. Microphotography showing characteristic nests of tumor cells separated by vascular septa (Zellballen) with cells showing significant nuclear pleomorphism with prominent nucleoli (H\&E, original magnification $\times 20)$.Synaptophysin immunostaining shows strong, diffuse cytoplasmic staining in the tumor cells. (immunostaining, original magnification $\times 20$ ). 


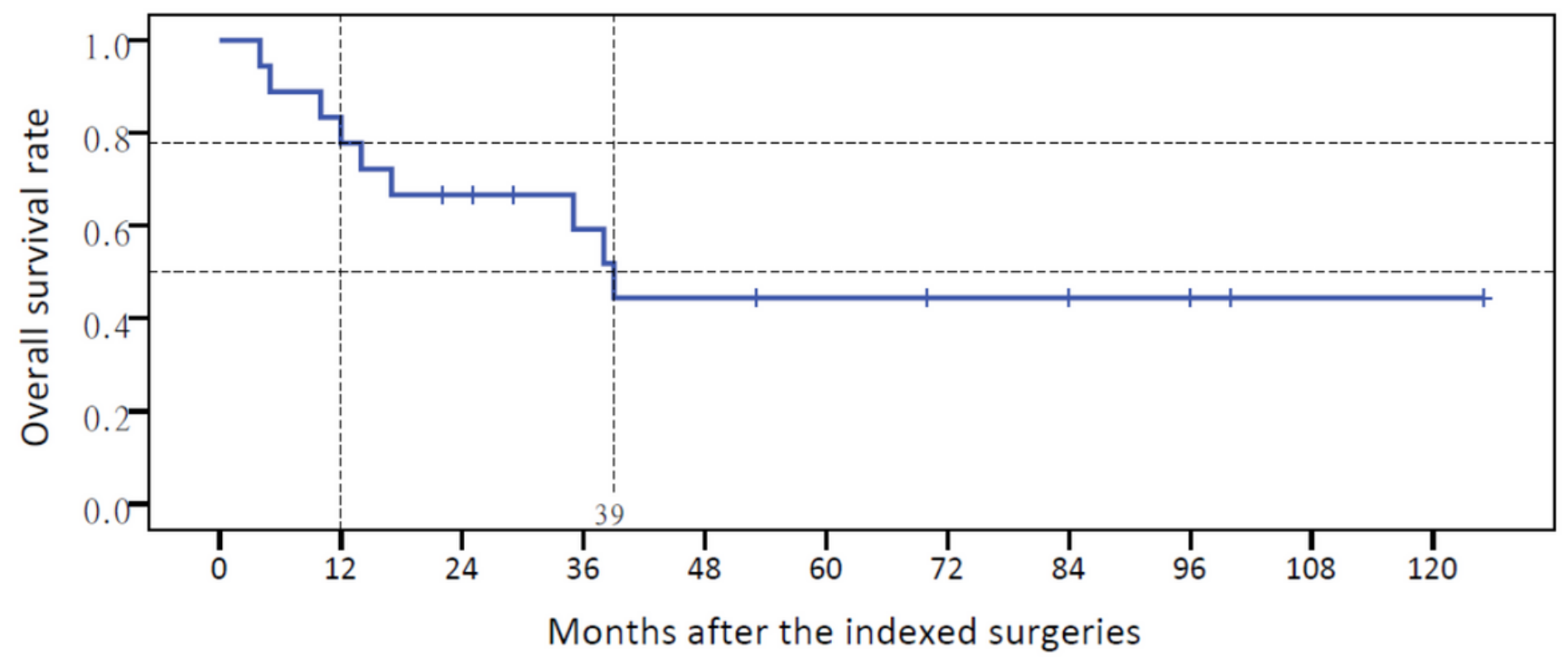

Figure 4

Kaplan-Meier survival curve of the cohort. 